\title{
Analisis Dana Pihak Ketiga, Kredit Bermasalah, dan Laba (Studi Kasus PT Bank X Tbk)
}

\author{
Heni Rohaeni \\ Departemen Manajemen, Fakultas Ekonomi dan Manajemen \\ Institut Pertanian Bogor \\ Wita Juwita Ermawati \\ Departemen Manajemen, Fakultas Ekonomi dan Manajemen \\ Institut Pertanian Bogor
}

\begin{abstract}
Economic growth is a measure of the national development of the world where banks play an important role in the stability of economic growth. The main function of banks is as a collector and distributor of public funds that aims to increase the standard of living people. Successfully collected funds will be channeled back in the form of credit. Currently, the bank main income is derived from distribution of credit. However, credit is also one of the factors that caused banking collapse when credit problems happened. So, management of funds of third parties becomes an important thing that it is a credit risk from funds distribution. This study aims to (1) Analyze the composition of third party funds (savings, giro, deposito), and (2) Analyze the development of DPK, NPL, and profit. Research conducted in the PT Bank X Tbk.

From the research, it was found that the composition of the funds of third parties on PT Bank $X$ is dominated by deposito that has the largest contribution to the total of $\operatorname{DPK}(56,50 \%)$, while savings and giro has contributed almost the same, namely that each of $21,90 \%$ and $21,61 \%$. There are fluctuations of DPK, NPL, and profit PT Bank $X$ during the period 1999-2007. DPK PT Bank $X$ was happening in the year 2007 amounting to $R p 247.355 .023$ (in million) with growth of $20,25 \%$ and the lowest occurred in 1999, amounting to $R p 148.005 .573$ (in millions). The lowest NPL happenned in the year 2004 amounting to 7,10\% and the highest occurred in 1999, amounting to $70,84 \%$. PT Bank $X$ has a relatively large loss in 1999, namely $R p$ 68.155 .446 (in millions) and then experienced a rapid development of year 2000 with profit growth of 103\%. However, in 2005 had experienced a decline of $84 \%$ but it could have been increased again in the years 2006 to 2007 those were 130\% and 124\% respectively.
\end{abstract}

Key words: Non Performing Loan (NPL), credit, third party funds, profit. 


\section{Pendahuluan}

Pertumbuhan ekonomi merupakan tolok ukur pembangunan nasional. Sektor ekonomi selalu menjadi fokus pemerintah dalam melaksanakan pembangunan baik jangka pendek maupun jangka panjang. Pertumbuhan ekonomi tidak dapat dilepaskan dari sektor perbankan. Dunia perbankan memegang peranan penting dalam pertumbuhan stabilitas ekonomi. Hal ini dapat dilihat ketika sektor ekonomi mengalami penurunan maka salah satu cara mengembalikan stabilitas ekonomi adalah menata sektor perbankan

Perbankan dalam menjalankan fungsinya berasaskan prinsip kehati-hatian. Fungsi utama perbankan adalah sebagai penghimpun dan penyalur dana masyarakat yang bertujuan untuk menunjang pelaksanaan pembangunan nasional dalam rangka meningkatkan taraf hidup masyarakat. Sebagai lembaga intermediasi, bank menerima simpanan dari nasabah dan meminjamkannya kepada nasabah (unit ekonomi) lain yang membutuhkan dana. Sumber dana terbesar yang dimiliki oleh bank berasal dari dana simpanan masyarakat atau dana pihak ketiga (DPK) yang berupa tabungan, giro dan deposito. Sumber dana tersebut akan disalurkan kembali kepada masyarakat dalam bentuk kredit. Atas simpanan masyarakat tersebut, bank memberikan imbalan berupa bunga. Menurut Siamat (2004), proporsi pendapatan terbesar bank berasal dari pendapatan bunga kredit yang disalurkan.

Industri perbankan adalah suatu industri yang rentan akan risiko, salah satunya dalam pemberian kredit. Kredit merupakan salah satu aktivitas bisnis perbankan yang memiliki risiko paling besar dan signifikan dari semua risiko yang menyebabkan kerugian potensial. Risiko kredit disini dimaksudkan sebagai ketidakmampuan debitur untuk melunasi kewajibannya kepada pihak bank. Apabila pinjaman yang tidak dapat dikembalikan jumlahnya cukup material, hal ini dapat menyebabkan turunnya pendapatan, kinerja maupun tingkat kesehatan dan kelangsungan bank.

Beberapa risiko kredit tak dapat dihindari, karena tanpa risiko tidak akan ada pendapatan. Besarnya jumlah kredit yang disalurkan akan menentukan keuntungan bank. Namun di sisi lain, kredit juga merupakan salah satu faktor yang menyebabkan rapuhnya usaha perbankan yaitu apabila kredit tersebut dinyatakan bermasalah. Besarnya kredit yang bermasalah ditunjukkan dalam nilai Non Performing Loan (NPL). Semakin besar NPL berarti risiko kredit semakin tinggi.

Saat ini, dunia perbankan di Indonesia mengalami kendala dengan tingkat kredit bermasalah yang meningkat. Bank Indonesia (BI) mencatat rasio kredit bermasalah (NPL) gross perbankan naik dari 4,33\% pada Maret menjadi 4,39\% per April 2008. Sementara NPL net pada periode yang sama naik dari $1,78 \%$ menjadi $1,8 \%$. Komposisi NPL tersebut adalah 3,7\% pada kredit modal kerja, kredit investasi 5,3\%, dan kredit konsumsi 3,1\% (www.zulfikargroup.blogspot.com).

PT Bank $X$ merupakan bank yang terbentuk sebagai bagian dari program restrukturisasi perbankan yang dilaksanakan oleh pemerintah Indonesia. PT Bank $X$ merupakan bank terbesar di Indonesia dilihat dari sisi jumlah aktiva, pemberian kredit, maupun dana pihak ketiga. PT Bank $X$ menyediakan berbagai produk dan jasa perbankan baik bagi nasabah perorangan, usaha kecil dan menengah (UKM), maupun korporasi dan badan usaha milik negara (BUMN). Sebagai lembaga intermediasi, bank 
memperoleh pendapatan dari bunga kredit atau surat-surat berharga. Pada tahun 2006 dan 2007, pendapatan bunga dari kegiatan penyaluran kredit memberikan kontribusi paling besar terhadap pencapaian laba PT Bank X. Pendapatan bunga kredit tersebut memiliki kontribusi masing-masing sebesar $43,1 \%$ dan $52,8 \%$. Nilai tersebut hampir mencapai setengah dari pendapatan bunga total (PT Bank X, 2007).

Dalam upaya pencapaian labanya, PT Bank $X$ harus terus berusaha menghimpun dana pihak ketiga untuk mendanai kegiatan penyaluran kreditnya dan selalu berusaha untuk menurunkan tingkat NPL. Semakin banyak dana yang disalurkan tentu saja semakin besar potensi menimbulkan risiko kredit. NPL yang tinggi akan berpengaruh terhadap citra perusahaan dan kinerja perbankan. Pengelolaan terhadap kegiatan penghimpunan dana dan penyaluran dana sangat penting dan berguna sebagai salah satu input alternatif dalam perumusan strategi tata kelola perusahaan. Berdasarkan latar belakang yang telah dikemukakan, maka perumusan masalah adalah sebagai berikut:

1. Bagaimana komposisi dana pihak ketiga (tabungan, giro, deposito) pada PT Bank X?

2. Bagaimana perkembangan dana pihak ketiga, NPL, dan laba pada PT Bank X?

Penelitian ini bertujuan untuk menganalisis komposisi dana pihak ketiga (tabungan, giro, deposito) dan menganalisis perkembangan dana pihak ketiga, NPL, dan laba pada PT Bank X.

\section{Metode Penelitian}

\section{II.1. Kerangka Pemikiran}

Sebagai lembaga intermediasi, bank mempunyai kegiatan utama yaitu menghimpun dan menyalurkan dana. Sumber dana terbesar yang dimiliki oleh bank berasal dari simpanan masyarakat yang berupa tabungan, giro, dan deposito. Sumber dana tersebut akan disalurkan kembali kepada masyarakat dalam bentuk kredit. Atas simpanan masyarakat tersebut, bank memberikan imbalan berupa bunga. Hampir semua kegiatan perekonomian masyarakat membutuhkan bank dengan fasilitas kreditnya. Oleh sebab itu, bank mempunyai peranan penting dalam pengelolaan dana yang beredar di masyarakat. Pendapatan terbesar bank berasal dari pendapatan bunga dari kredit yang disalurkan (Siamat, 2004). Sedangkan jumlah kredit yang disalurkan tersebut ditentukan oleh besarnya sumber dana yang diperoleh dari masyarakat. Namun dalam merealisasikan kegiatan bisnisnya, kredit selalu dihubungkan dengan prinsip risk and return, di mana kegiatan yang diharapkan akan mempunyai hasil atau pendapatan yang besar, biasanya mempunyai risiko yang tinggi.

Dalam penelitian ini, sumber pendanaan bank yang digunakan adalah sumber dana yang berasal dari pihak ketiga yang terdiri dari tabungan, giro, dan deposito. Besarnya risiko kredit ditunjukkan dalam nilai Non Performing Loan (NPL). Tingginya NPL menunjukkan banyaknya pihak debitur yang tidak dapat membayar secara kontinu atas pinjaman kreditnya. Sedangkan laba bank yang digunakan adalah laba bersih sebelum dikurangi pajak. 


\section{II.2. Lokasi dan Waktu Penelitian}

Penelitian dilaksanakan di PT Bank $X$ yang berlokasi di Jakarta. Pemilihan tempat dilakukan secara purposive. Waktu penelitian dimulai dari bulan Februari 2009 sampai April 2009.

\section{II.3. Jenis dan Metode Pengumpulan Data}

Data yang dikumpulkan dari penelitian ini adalah data sekunder. Data sekunder merupakan data yang telah diolah lebih lanjut dan disajikan, baik oleh pihak pengumpul data atau oleh pihak lain misalnya dalam bentuk tabel, diagram, dan lainlain (Juanda 2003). Data sekunder diperoleh dari data historis PT. Bank X, literatur, laporan penelitian, dan laporan keuangan yang diterbitkan bank maupun internet.

\section{II.4. Metode Pengolahan dan Analisis Data}

Dalam penelitian ini, data yang diperoleh hanya dianalisis dengan metode analisis deskriptif. Analisis deskriptif merupakan analisis yang digunakan untuk menganalisis data dengan cara mendeskripsikan atau menggambarkan data yang terkumpul sebagaimana adanya tanpa bermaksud membuat kesimpulan yang berlaku untuk umum atau generalisasi (Sugiono dalam_Gumayantika 2008).

\section{Hasil Penelitian}

\section{III.1. Penghimpunan Dana}

Produk penghimpunan dana pada PT Bank $\mathrm{X}$ terdiri dari tabungan $\mathrm{x}$, giro, deposito, deposito on call, tabungan haji, tabungan rencana $x$, tabungan bisnis $x$, tabungan valas $x$, tabungan kapel, tabungan TKI, dan tabungan mikro. Kebutuhan dana untuk melakukan ekspansi kredit dipenuhi Bank $X$ dengan mengelola beberapa sumber dana. Sumber utama dana bank berasal dari penghimpunan dana yang berupa simpanan dalam bentuk tabungan, giro, dan deposito. Sumber-sumber dana bank dalam bentuk simpanan tersebut berasal dari masyarakat maupun dari nasabah institusi. Gambar 1 menunjukkan komposisi dana pihak ketiga PT Bank X selama periode 1999-2007.

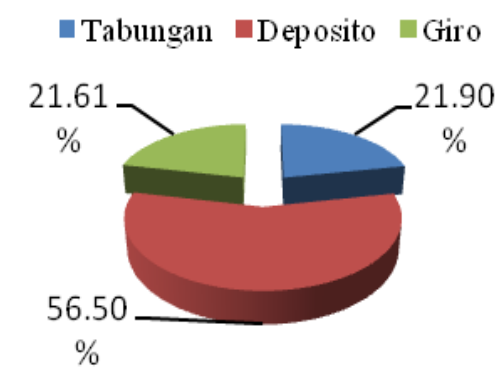

Gambar 1. Komposisi Dana Pihak Ketiga PT Bank X periode 1999-2007. Sumber: PT Bank X (Data Diolah)

Selama periode 1999-2007, deposito memiliki kontribusi yang sangat besar tehadap total DPK yang berhasil dihimpun oleh PT Bank X yaitu sebesar 56,50\%, sedangkan tabungan memberikan kontribusi yang tidak berbeda jauh dengan giro yaitu masingmasing sebesar $21,90 \%$ dan $21,61 \%$. Dana yang cukup tinggi akan berimplikasi pada 
kemampuan PT Bank X untuk menyalurkan kreditnya, karena untuk melakukan ekspansi kredit dibutuhkan dana yang memenuhi. Permintaan terhadap kredit yang cukup tinggi harus diimbangi dengan dana yang tersedia. Aliran pemikiran ekonomi moneter Keynes menyatakan bahwa meningkatnya penawaran uang atau uang beredar akan meningkatkan ketersediaan dana yang dapat dipinjamkan atau loanable funds.

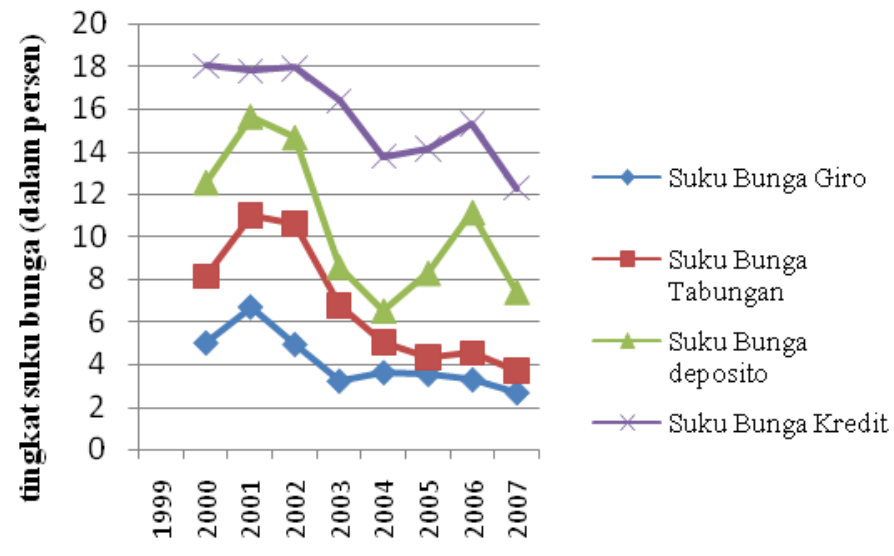

Tahun

Gambar 2. Grafik Perkembangan DPK dan Kredit periode 1999-2007. Sumber: PT Bank $\mathrm{X}$ (Data Diolah)

Berdasarkan Gambar 2 dapat diketahui perkembangan DPK yang dihimpun oleh PT Bank X selama jangka waktu sembilan tahun yaitu mulai tahun 1999 sampai dengan tahun 2007, Deposito selalu menjadi pemberi kontribusi terbesar terhadap total DPK yang berhasil dihimpun PT Bank X dibandingkan dengan giro dan tabungan. Giro dan tabungan memiliki kontribusi yang tidak berbeda jauh setiap tahunnya.

Besarnya kontribusi deposito terhadap DPK disebabkan oleh tingkat suku bunga deposito yang lebih besar dari dua jenis DPK lainnya. Seperti terlihat pada Gambar 3, sepanjang tahun 1999 sampai 2007 tingkat suku bunga deposito selalu lebih besar daripada dua produk simpanan lainnya sehingga para nasabah lebih tertarik untuk menyimpan uangnya pada produk simpanan ini walaupun memiliki jangka waktu yang lebih lama daripada produk tabungan maupun giro. Tingkat suku bunga simpanan selalu lebih rendah daripada tingkat suku bunga pinjaman atau kredit sehingga menghasilkan spread (selisih) yang positif.

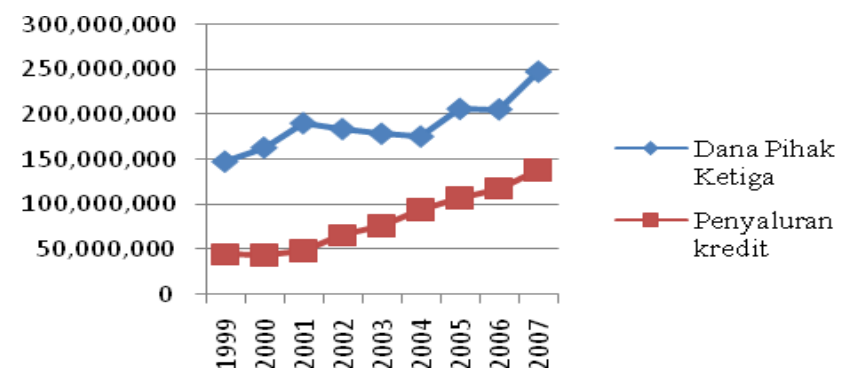

Gambar 3. Grafik Perkembangan Tingkat Suku Bunga Dana dan Suku Bunga Kredit PT Bank X periode 1999-2007. Sumber: PT Bank X (Data Diolah 


\section{III.2. Penyaluran Dana}

Produk penyaluran dana pada PT Bank $\mathrm{X}$ terdiri dari kredit modal kerja, kredit investasi, kredit agunan tunai, kredit modal kerja komoditas, kredit modal kerja dengan fasilitas e-Biz Card $\mathrm{x}$, kredit multiguna usaha (KMU), kredit agunan deposito, kredit koperasi $x$, kredit wirausahawan $\mathrm{x}$, kredit usaha mikro, kredit serbaguna mikro, program kemitraan dan bina lingkungan, kredit ketahanan pangan dan energi (KKP-E), KPR graha $x$, KPR graha $x$ angsuran berjenjang, kredit multiguna $x$, kredit mitrakarya $x$, kredit tanpa agunan dan KPM kendara $x$.

Kegiatan usaha perbankan yang paling utama adalah penyaluran kredit. PT Bank X merupakan bank yang termasuk kategori bank terbesar dilihat dari segi penyaluran kreditnya. Kredit yang disalurkan tersebut berasal dari modal sendiri, pinjaman dari lembaga lain dan yang paling utama berasal dari dana pihak ketiga. Penyaluran kredit memberikan kontribusi paling besar terhadap pencapaian laba bank karena sebagian besar dana yang dihimpun akan disalurkan dalam bentuk kredit. Perkembangan penyaluran kredit PT Bank $X$ cenderung mengalami peningkatan dari tahun ke tahun seperti terlihat pada tabel di bawah ini:

Tabel 1. Persentase Tingkat Pertumbuhan Penyaluran Kredit Periode 1999-2007

\begin{tabular}{rrc}
\hline Tahun & $\begin{array}{c}\text { Jumlah Kredit yang } \\
\text { Disalurkan }\end{array}$ & $\begin{array}{c}\text { Tingkat } \\
\text { Pertumbuhan }\end{array}$ \\
\hline 1999 & $44,022,662$ & \\
2000 & $43,022,539$ & $-2.27 \%$ \\
2001 & $48,185,786$ & $12.00 \%$ \\
2002 & $65,417,248$ & $35.76 \%$ \\
2003 & $75,942,620$ & $16.09 \%$ \\
2004 & $94,434,739$ & $24.35 \%$ \\
2005 & $106,852,946$ & $13.15 \%$ \\
2006 & $117,757,322$ & $10.21 \%$ \\
2007 & $138,553,552$ & $17.66 \%$ \\
\hline
\end{tabular}

Sumber: PT Bank X (Data Diolah)

Kredit yang disalurkan mengalami peningkatan setiap tahunnya mulai dari tahun 2001-2007, walaupun pada awalnya sempat mengalami penurunan yaitu pada tahun 2000. Pada tahun 2000 penyaluran kredit menurun sebesar 2,27\% dan berhasil ditingkatkan kembali di tahun 2001 sebesar 12\%. Peningkatan tersebut berlangsung hingga tahun 2007. Hal ini terjadi karena PT Bank X mempunyai dana pihak ketiga yang besar sehingga dapat memenuhi permintaan uang yaitu dalam bentuk kredit yang besar pula. Penyaluran kredit tersebut dipengaruhi oleh penawaran uang yang besar.

\section{III.3. Kredit Bermasalah}

Masalah yang dihadapi perbankan adalah ketika debitur tidak mampu membayar kembali baik pokok maupun bunganya kepada pihak bank. Ketidakmampuan tersebut dinamakan kredit bermasalah atau kredit gagal bayar yang dapat ditunjukkan oleh rasio Non Performing Loan (NPL). Bank Indonesia mengklasifikasikan kualitas kredit 
dalam lima kolektibilitas. Kredit diklasifikasikan menjadi kredit kualitas lancar, dalam perhatian khusus, kurang lancar, diragukan, dan macet. Kredit dengan kualitas lancar, dan dalam perhatian khusus digolongkan ke dalam kredit tidak bermasalah, sedangkan kredit dengan kualitas kurang lancar, diragukan dan macet digolongkan dalam kredit bermasalah.

NPL adalah kredit yang tidak diikuti oleh pelunasan pembayaran pokok atau angsuran sebagaimana yang telah dipersyaratkan dalam perjanjian kredit. Kredit dengan kolektibilitas kurang lancar, diragukan, dan macet termasuk dalam NPL. Rasio NPL diperoleh dari pembagian antara NPL dengan total kredit yang diberikan. Semakin besar rasio NPL, semakin tinggi pula risiko yang ditanggung oleh pihak bank dan menunjukkan kegagalan bank dalam mengelola dana yang ada. Nilai NPL akan mempengaruhi laba yang diperoleh dan akan menentukan posisi bank tersebut dinyatakan sehat atau tidak. Berdasarkan aturan BI, bank wajib memiliki NPL neto dibawah 5 persen. Jika tidak, bank akan masuk dalam program pengawasan intensif atau pengawasan khusus oleh BI.

NPL PT Bank X mengalami fluktuasi setiap tahunnya. NPL terendah terlihat pada tahun 2004 yaitu sebesar 7,10 \% untuk NPL bruto dan 1,87\% untuk NPL neto dan tertinggi ditunjukan pada tahun 1999 yaitu sebesar 70,84\% dengan NPL neto 20,57\%. Pada tahun 1999 merupakan tahun di mana PT Bank X mencatat tingkat NPL Bruto tertinggi sepanjang tahun 1999 sampai tahun 2007. Tingginya NPL yang di alami PT Bank X merupakan dampak dari terjadinya krisis ekonomi dan moneter Negara Indonesia pada tahun 1997. Krisis ekonomi tersebut merapuhkan dunia perbankan dan salah satunya PT Bank X. Akibat dari krisis ekonomi tersebut, tingkat inflasi melonjak begitu tinggi pada tahun 1998 yaitu sebesar 77,56\% yang mendorong peningkatan indeks harga konsumen, sehingga puluhan bahkan ratusan perusahaan mulai dari skala kecil hingga konglomerasi mengalami kebangkrutan. Sekitar 70 persen lebih perusahaan yang tercatat di pasar modal juga insolvent (bangkrut) dan akhirnya menurunkan kemampuan mereka untuk melunasi baik pokok maupun bunga yang dibebankan kepada pihak debitur.

Tabel 2. Persentase Non Performing Loan (NPL) kredit periode 1999-2007 (dalam jutaan rupiah)

\begin{tabular}{cccccc}
\hline Tahun & NPL (Rp) & $\begin{array}{c}\text { Penyaluran Kredit } \\
(\text { Rp })\end{array}$ & NPL Bruto & PPAP & NPL neto \\
\hline 1999 & 31.186 .141 & 44.022 .662 & $70,84 \%$ & 22.131 .786 & $20,57 \%$ \\
2000 & 8.518 .665 & 43.022 .539 & $19,80 \%$ & 12.499 .948 & $9,25 \%$ \\
2001 & 4.712 .146 & 48.185 .786 & $9,78 \%$ & 6.098 .717 & $2,88 \%$ \\
2002 & 4.763 .823 & 65.417 .248 & $7,28 \%$ & 8.906 .545 & $6,33 \%$ \\
2003 & 6.541 .812 & 75.942 .620 & $8,61 \%$ & 8.890 .383 & $3,09 \%$ \\
2004 & 6.703 .613 & 94.434 .739 & $7,10 \%$ & 8.471 .343 & $1,87 \%$ \\
2005 & 27.013 .758 & 106.852 .946 & $25,28 \%$ & 11.823 .614 & $14,22 \%$ \\
2006 & 19.261 .927 & 117.757 .322 & $16,36 \%$ & 14.388 .695 & $4,14 \%$ \\
2007 & 11.968 .108 & 138.553 .552 & $8,64 \%$ & 13.041 .696 & $0,77 \%$ \\
\hline Sumber: PT Bank
\end{tabular}

Sumber: PT Bank X (Data Diolah)

Pada tahun 2000, tingkat inflasi mulai turun sampai 9,35\% dan PT Bank X mulai merestrukturisasi kreditnya sehingga pada tahun ini dapat menekan tingkat NPL sampai $19,80 \%$ dengan NPL neto $9,25 \%$. Penurunan NPL tersebut terus dialami sampai 
tahun 2004, dan kembali meningkat pada tahun 2005 sampai mencapai 25,28\% dengan NPL neto $14,22 \%$. Perkembangan rasio NPL dapat dilihat pada Gambar 4.

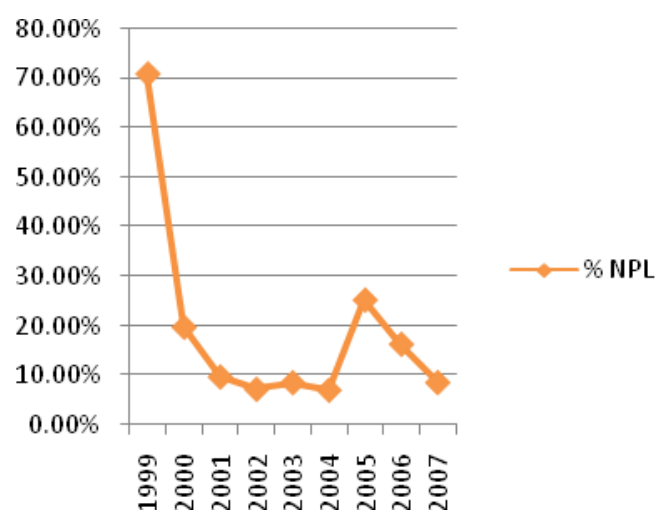

Gambar 4. Grafik Perkembangan Rasio NPL PT Bank X periode 1999-2007 Sumber: PT Bank X (Data diolah)

III.4. Laba

Laba yang diperoleh suatu bank menunjukkan keberhasilan perusahaan tersebut dalam mengelola usahanya, baik dalam penghimpunan dana maupun penyaluran kreditnya. Laba memiliki peranan yaitu sebagai tujuan setiap perusahaan untuk memperoleh laba yang tinggi, tolok ukur efektivitas, selisih pendapatan dengan biaya, dan mengukur efisiensi dan efektivitas. Peningkatan laba dari periode ke periode berikutnya dapat dijadikan gambaran bagi pihak yang berkepentingan dalam rangka pengambilan keputusan. Laba PT Bank $X$ diperoleh dari pendapatan bunga kredit, obligasi rekapitalisasi pemerintah, surat berharga, pendapatan operasional lainnya, dan pendapatan bukan operasional. Laba yang diperoleh dari kegiatan penyaluran kredit merupakan pendapatan utama dari sebuah bank. Pendapatan tersebut berasal dari pendapatan bunga kredit, provisi dan komisi kredit. Akan tetapi, pendapatan bunga obligasi rekapitalisasi pemerintah memiliki kontribusi terbesar pada laba PT Bank X di tahun 2001.

Pada tahun 1999, PT Bank X mengalami kerugian yang cukup besar yaitu Rp 68.155.446.000.000. Kerugian tersebut disebabkan oleh tingginya tingkat NPL bruto sebesar $70,84 \%$ dengan NPL neto $20,57 \%$. NPL yang tinggi merupakan dampak dari terjadinya krisis ekonomi dan moneter pada tahun 1997. Laba PT Bank X mengalami peningkatan yang pesat pada tahun 2000 setelah kerugian yang disebabkan oleh tingginya NPL pada tahun 1999. Pertumbuhannya sebesar $103 \%$ dengan nilai sebesar Rp 2.023.479.000.000. Peningkatan tersebut terjadi sampai tahun 2004 seperti terlihat pada Gambar 5. Pada tahun 2000, PT Bank X telah berhasil menagih pokok dan bunga kredit bermasalah sebesar 6,3 triliun dan hal itu berlanjut sampai tahun-tahun berikutnya. Pada tahun 2005 PT Bank X sempat mengalami penurunan laba sebesar $84 \%$ yang diakibatkan oleh peningkatan NPL bruto sampai $25,28 \%$ yang terlihat pada 
gambar 5. Namun setelah penurunan tersebut, pada tahun 2006 sampai 2007 laba PT Bank X kembali meningkat.

\begin{tabular}{ccc}
\multicolumn{3}{c}{ Tabel 3. Laba PT Bank X periode 1999-2007 (dalam jutaan rupiah) } \\
\hline \multirow{2}{*}{ Tahun } & Laba bersih sebelum pajak & Tingkat Pertumbuhan \\
\hline 1999 & $-68,155,446$ & \\
2000 & $2,023,479$ & $103 \%$ \\
2001 & $3,850,438$ & $90 \%$ \\
2002 & $5,809,970$ & $51 \%$ \\
2003 & $7,031,524$ & $21 \%$ \\
2004 & $7,525,002$ & $7 \%$ \\
2005 & $1,232,553$ & $-84 \%$ \\
2006 & $2,831,196$ & $130 \%$ \\
2007 & $6,333,383$ & $124 \%$ \\
\hline
\end{tabular}

Sumber: PT Bank X (Data Diolah)

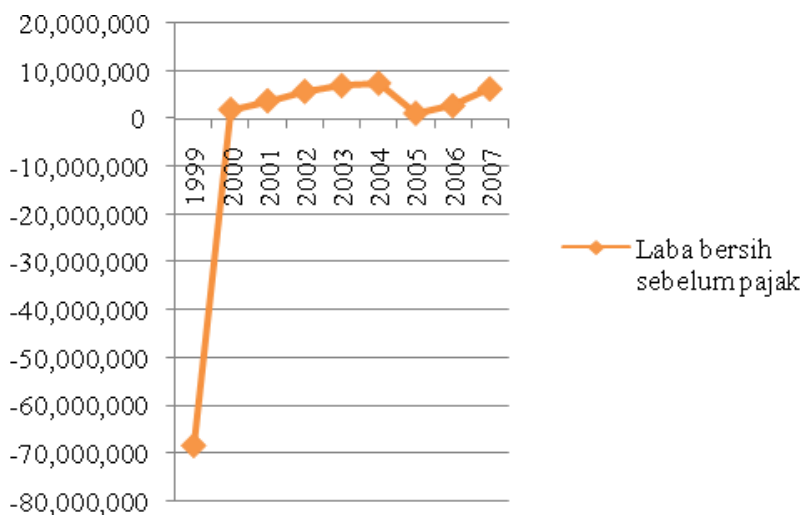

Gambar 5. Grafik Perkembangan Laba PT Bank X periode 1999-2007. Sumber: PT Bank $X$ (Data Diolah)

\section{Kesimpulan}

Komposisi dana pihak ketiga PT Bank X selama periode 1999-2007 didominasi oleh deposito yang memiliki kontribusi terbesar terhadap total DPK yaitu sebesar $56,50 \%$. Sedangkan tabungan dan giro memiliki kontribusi yang hampir sama yaitu masingmasing sebesar 21,90\% dan 21,61\%. Baik DPK, NPL, dan laba PT Bank X mengalami fluktuasi selama periode 1999-2007. Di mana DPK tertinggi terjadi pada tahun 2007 yaitu sebesar Rp 247.355.023 (dalam jutaan) dengan pertumbuhan sebesar 20,25\% dan terendah terjadi pada tahun 1999 yaitu sebesar 148.005 .573 (dalam jutaan). NPL terendah terjadi pada tahun 2004 yaitu sebesar 7,10\% dan tertinggi terjadi pada tahun 1999 yaitu sebesar 70,84\%. PT Bank X mengalami kerugian yang cukup besar pada tahun 1999 yaitu Rp 68.155.446 (dalam jutaan) dan kemudian mengalami perkembangan yang cukup pesat di tahun 2000 dengan pertumbuhan laba sebesar 103\%. Akan tetapi pada tahun 2005 sempat mengalami penurunan sebesar $84 \%$ namun dapat ditingkatkan kembali di tahun 2006 sampai 2007. 


\section{Daftar Pustaka}

Gumayantika, R. 2008. Analisis Manajemen Risiko Kredit dan Pengaruhnya Terhadap Laba Perusahaan dengan Penerapan Program Komputer (Studi Kasus PT. Bank Jabar Cabang Ciamis). Skripsi pada Departemen Manajemen, Fakultas Ekonomi dan Manajemen, Institut Pertanian Bogor, Bogor.

Juanda, B. 2003. Metode Statistik. Departemen Statistika Institut Pertanian Bogor, Bogor.

Kasmir. 2008. Manajemen Perbankan. RajaGrafindo Persada, Jakarta.

PT Bank X. 2000. Laporan Keuangan Tahun 1999. Jakarta. PT Bank X . 2001. Laporan Keuangan Tahun 2000. Jakarta. PT Bank X . 2002. Laporan Keuangan Tahun 2001. Jakarta. PT Bank X . 2003. Laporan Keuangan Tahun 2002. Jakarta. PT Bank X . 2004. Laporan Keuangan Tahun 2003. Jakarta. PT Bank X . 2005. Laporan Keuangan Tahun 2004. Jakarta. PT Bank X . 2006. Laporan Keuangan Tahun 2005. Jakarta. PT Bank X . 2007. Laporan Keuangan Tahun 2006. Jakarta. PT Bank X

Rivai, V. dan A.P. Veithzal. 2005. Credit Management Handbook. RajaGrafindo Persada, Jakarta.

Siamat, D. 2004. Manajemen Lembaga Keuangan. Fakultas Ekonomi Universitas Indonesia, Jakarta.

Zulfikar. 2008. BI: Pertumbuhan Ekonomi Indonesia 2009. www.zulfikargroup. blogspot.com. [17 Februari 2009]. 